\title{
Significance of graphite occurrences in the Aracena Metamorphic Belt, Iberian Massif
}

\author{
ELENA CRESPO*, JAVIER LUQUE*†, CARLOS FERNÁNDEZ-RODRÍGUEZ $\ddagger$, \\ MAGDALENA RODAS*, MANUEL DÍAZ-AZPIROZ§, \\ JUAN CARLOS FERNÁNDEZ-CALIANII \& JOSÉ F. BARRENECHEA*
}

*Dpto. Cristalografía y Mineralogía, Fac. Geología, Universidad Complutense de Madrid, 28040 Madrid, Spain $\ddagger$ Dpto. Geodinámica y Paleontología, Fac. de Ciencias Experimentales, Universidad de Huelva, 21071 Huelva, Spain $\S$ Dpto. de Ciencias Ambientales, Universidad Pablo de Olavide, 41013 Sevilla, Spain ФDpto. Geología, Fac. de Ciencias Experimentales, Universidad de Huelva, 21071 Huelva, Spain

\section{(Received 23 March 2004; accepted 20 July 2004)}

\begin{abstract}
The significance of syngenetic and epigenetic graphite occurrences from the Variscan hightemperature/low-pressure Aracena Metamorphic Belt is discussed in the framework of the tectonothermal evolution of this southern zone of the Iberian Massif. Syngenetic graphite is associated with both low- to medium-grade metamorphic rocks (La Umbría series, Precambrian in age) and high-grade, granulite facies rocks (the Precambrian Fuente del Oro series and a Cambrian calc-silicate series). Epigenetic, fluid-deposited occurrences correspond to overgrowths on existing metamorphic graphite grains and vein-type mineralization. Two types of graphitized particles with remarkable differences in reflectance, anisotropy and size can be distinguished in the Precambrian metapelites of the La Umbría series. Large, $>150 \mu \mathrm{m}$ length, platy crystals with high reflectance and anisotropy are interpreted as detrital and are considered indirect evidence of an old orogenic cycle prior to the Cadomian Orogeny, during which metamorphism exceeded greenschist facies. The coexistence of two types of particles explains the scattering of values of the $\mathrm{c}$ parameter of graphite determined by XRD $(\mathrm{c}=6.72-6.74 \AA)$, and the anomalously high temperatures of the DTA exothermic peak (close to $600^{\circ} \mathrm{C}$ ) of graphite with respect to that inferred from mineral assemblages in these rocks. The presence of graphite-rich quartzites and gneisses within the Fuente del Oro series and the calc-silicate series is evidence of sedimentation under reducing conditions in a continental shelf. The characteristics of graphite reflect the high-grade metamorphic conditions attained in the southern area of the Aracena Metamorphic Belt. Pervasive flow of fluids related to a major Variscan extensional event resulted in overgrowths on the pre-existing graphite in the gneisses and quartzites of the calc-silicate series, as evidenced by the heterogeneous isotopic composition of graphite single crystals in these rocks. A later stage of graphite precipitation is represented by scarce vein-type occurrences in mafic granulites that document channelled flow of fluids.
\end{abstract}

Keywords: graphite, metamorphism, P-T conditions, Aracena Spain.

\section{Introduction}

Natural graphite is formed by either of two processes: (1) in situ metamorphism of organic matter through the so-called 'graphitization' (syngenetic graphite), and (2) precipitation from $\mathrm{C}-\mathrm{O}-\mathrm{H}$ fluids (epigenetic graphite). Syngenetic graphite usually occurs as stratabound disseminated to massive concentrations. Epigenetic graphite may occur as veins (Luque et al. 1998) or as overgrowths on existing metamorphic graphite grains in areas where pervasive fluid flow took place (Farquhar, Hauri \& Wang, 1999; Satish-Kumar, Wada \& Santosh, 2002; Ueno et al. 2002). Graphitization differs from most mineral transformations occurring during diagenesis and metamorphism in that it is an irreversible process (Grew, 1974; Buseck \&

$\dagger$ Author for correspondence: jluque@geo.ucm.es
Bo-Jun, 1985; Beyssac et al. 2002a). Therefore, certain physical parameters of graphite could be used for the estimation of peak metamorphic temperature of its host rocks (Shengelia, Akhvlediani \& Ketskhoveli, 1979; Itaya, 1981; Luque, Barrenechea \& Rodas, 1993; Beyssac et al. 2002b). In addition, syngenetic graphite can be used for tracing ancient organic-rich sedimentary basins. The closure of such basins resulted in the formation of geosutures, and metamorphic graphite in these occurrences may indicate the location of former crustal fragments (Wilde, Dorsett-Bain \& Lennon, 1999; Dissanayake, Chandrajith \& Boudou, 2000). On the other hand, the study of fluid-deposited graphite provides valuable information on the nature of the carbon phases and the temperatures of equilibration over a wide range of rock types (Kitchen \& Valley, 1995; Barrenechea et al. 1997; Pasteris \& Chou, 1998; Pasteris, 1999; among many others). 


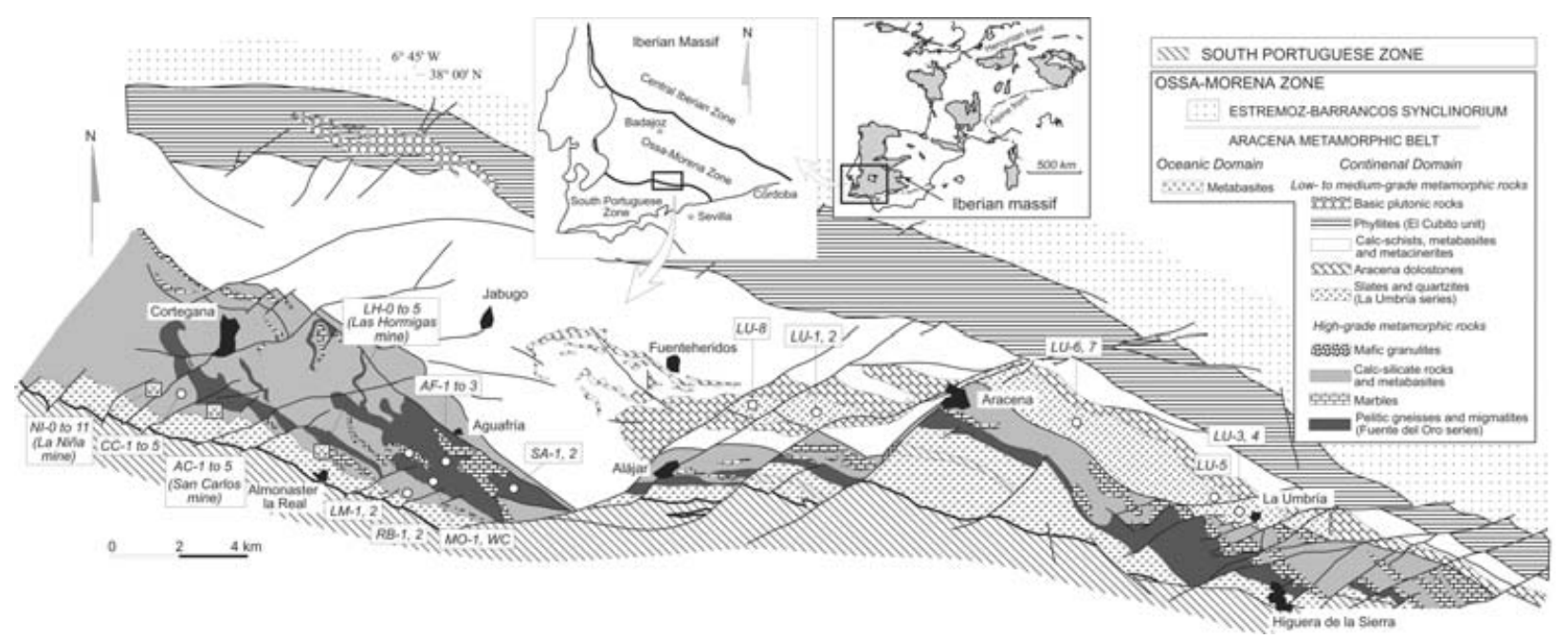

Figure 1. Location and generalized geological map of the Aracena Metamorphic Belt. Sampling areas are indicated (for further details on high-grade samples, see Rodas et al. 2000).

The aim of this paper is to examine the significance of graphite occurrences in the framework of the Aracena Metamorphic Belt, thus providing additional data to constrain the tectono-thermal model available for this complex metamorphic belt of the European Variscan Chain.

\section{Regional geology and tectono-thermal evolution of the Aracena Metamorphic Belt}

The Aracena Metamorphic Belt is located at the boundary between the Ossa-Morena Zone and the South Portuguese Zone of the Iberian Massif(Fig. 1). It is more than $100 \mathrm{~km}$ long and tens of kilometres wide.

The tectono-thermal evolution of the Aracena Metamorphic Belt has been studied by different authors who have applied contrasting structural and petrological techniques (Bard, 1969; Ábalos, Gil Ibarguchi \& Eguiluz, 1991; Dallmeyer et al. 1993; Giese et al. 1994; Quesada et al. 1994; Castro et al. 1996a,b, 1999; Díaz-Azpiroz et al. 2004). According to Castro et al. $(1996 a, b)$, the Aracena Metamorphic Belt can be divided into two main domains: a southern oceanic domain and a northern continental domain. The continental domain was metamorphosed during the Variscan orogeny and displays a strong metamorphic gradient. The northern part of the continental domain underwent low- to medium-grade metamorphism that mainly affected the Precambrian sediments (now represented by slates and quartzites of La Umbría series; cf. Bard, 1969). Although older in age (upper Riphean), these Precambrian sediments of the La Umbría series do not show the deformational and metamorphic effects associated with the Cadomian Orogeny (Ábalos \& Díaz Cusí, 1995).

In the high-temperature southern part of the continental domain, the Variscan metamorphism reached granulite-facies conditions in both the Precambrian sedimentary units (now represented by pelitic gneisses, quartzites and anatectic tonalites; cf. Fuente del Oro series of Bard, 1969) and in the younger calc-silicate sequence (now composed mainly of calc-silicate rocks and leucogneisses, with intercalations of marbles, amphibolites, quartzites and mafic granulites; that is, the calc-silicate series of Fernández-Rodríguez et al. 1996). Gneisses and quartzites from the Fuente del Oro series have been considered as the high-grade equivalents of the La Umbría series according to regional correlations (Bard, 1969). Petrological studies reveal that in this area the metamorphism developed under ultrahigh- $T /$ low- $P$ (UHT/LP) conditions according to phase equilibria relations and by using conventional thermobarometric determination techniques (Bard, 1969; Castro et al. 1996a; Patiño Douce, Castro \& El-Biad, 1997; Díaz-Azpiroz et al. 2004) (Fig. 2).

Four ductile deformation phases affected the continental domain of the Aracena Metamorphic Belt (Díaz-Azpiroz et al. 2004). The older phase (D1) gave place to large-scale recumbent folds vergent to the south, and it was followed by a second extensional phase (D2). Afterwards, the continental domain was deformed by two contractional phases (D3 and D4) that influenced its final geometrical configuration through the generation of a complex pattern of superposed folding and the activity of ductile shear zones. The temperature peak is coincident with the $\mathrm{D} 2$ extensional phase.

The metamorphic $P-T$ path is very unusual, suggesting that exhumation was virtually complete $(\mathrm{P} \approx 1 \mathrm{kbar})$ at very high $T\left(800^{\circ} \mathrm{C}\right)$ and it requires an extremely anomalous tectonic setting. A tectonic model based on the evolution of a trench-trench-ridge triple junction among three tectonic plates can explain such an unusual $P-T$ path (Castro et al. 1996a), as shown schematically in Fig. 3. 


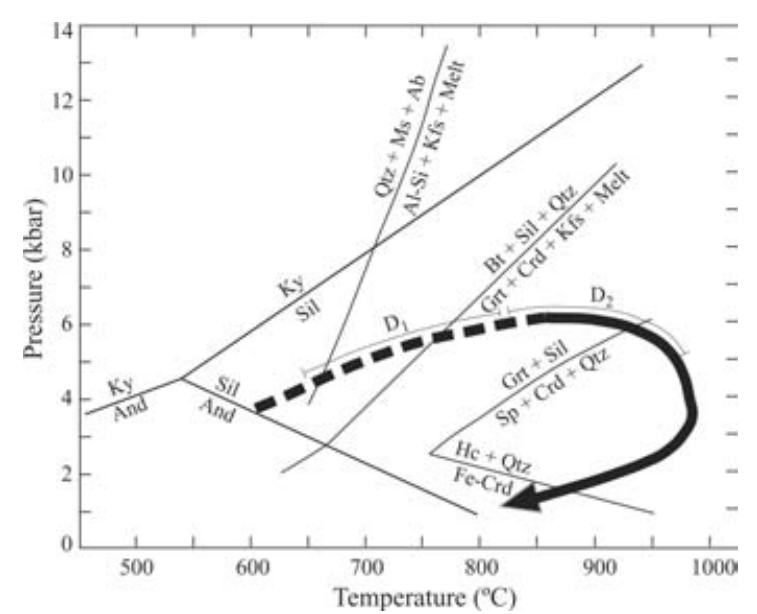

Figure 2. $P-T-d$ path in the NaKFMASH system deduced from petrography and the use of conventional thermobarometric determination techniques in the pelitic series of the Continental Domain (Patiño Douce, Castro \& El-Biad, 1997; Díaz Azpiroz et al. 2004). The dashed segment was inferred from indirect observations. Mineral abbreviations after Kretz (1983): Crd cordierite; Qtz - quartz; Grt - garnet; Kfs - K-feldspar; Sil sillimanite; $\mathrm{Ab}$ - albite; $\mathrm{Bt}$ - biotite; $\mathrm{Hc}$ - hercynite; $\mathrm{Sp}$ - spinel; Ky - kyanite; And - andalusite.

\section{Analytical methods}

The characteristics of graphite in the high-grade rocks of the Aracena Metamorphic Belt were previously reported by Rodas et al. (2000) using optical microscopy, X-ray diffraction (XRD), thermal analysis (DTA-TG) and bulk carbon isotopic analysis. The optical, structural, thermal and isotopic characteristics of graphite occurrences in the La Umbría series are reported here for the first time and they have been investigated with the same analytical techniques used for the high-grade occurrences. Location and number of collected samples are shown in Fig. 1. The analytical equipment and experimental conditions are detailed in Rodas et al. (2000).

The structural characterization of graphite in highgrade samples has been completed using Raman spectroscopy on grain separates. The Raman analyses were done at ITODYS, Université Denis Diderot (Paris VII) using a Dilor WY double monochromator with multichannel detection system in micro-Raman mode. Excitation was provided by the $514.5 \mathrm{~nm}$ line of a $100 \mathrm{~mW}$ Ar-ion laser with about 3-5 mW power at the sample surface. Each sample was scanned five times from 900 to $1700 \mathrm{~cm}^{-1}$ (first order spectrum) and 2400 to $3200 \mathrm{~cm}^{-1}$ (second order spectrum) in order to check the reproducibility of the analyses. Labspec 5.0 software was used to determine all the parameters in the spectra (peak position, peak height, peak width (FWHM), and peak area) from which the area ratio of the $\mathrm{D}$ (disorder peak, at $\approx 1360 \mathrm{~cm}^{-1}$ ) to $\mathrm{O}$ (order peak, at $\approx 1582)$ was calculated. The $(\mathrm{D} / \mathrm{D}+\mathrm{O}) \times 100$ area ratio is inversely correlated with the in-plane crystallite sizes $\left(\mathrm{L}_{\mathrm{a}}\right)$ which has been calculated from the estim-

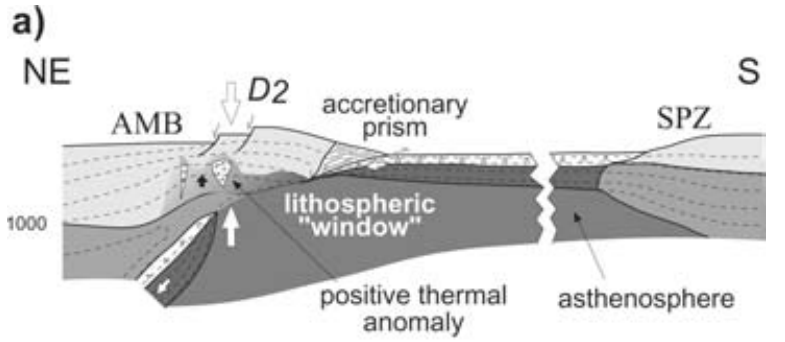

b)

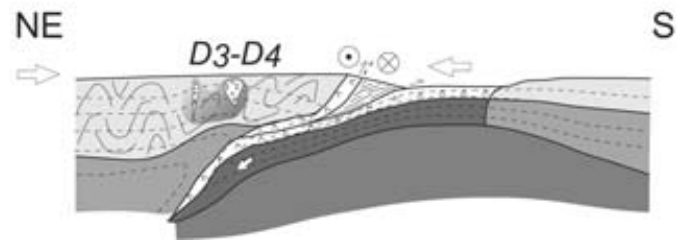

Figure 3. Idealized figures showing the tectonic model proposed for the Variscan evolution of the Aracena Metamorphic Belt. (a) Subduction of a ridge during the Visean, as a consequence of a TTR triple junction migration. The opening of a lithospheric window heated up the base of the continental crust (the continental domain of the Aracena Metamorphic Belt), which was subjected to an extensional regime $\left(D_{2}\right)$. (b) Afterwards, during the Namurian and Westphalian, the Aracena Metamorphic Belt was deformed as a consequence of the subduction of the trailing oceanic plate $\left(\mathrm{D}_{3}\right)$ and the subsequent collision between the Aracena Metamorphic Belt and the South Portuguese Zone continent $\left(\mathrm{D}_{4}\right)$. AMB - Aracena Metamorphic Belt; SPZ - South Portuguese Zone.

ations of Wopenka \& Pasteris (1993) and Matthews et al. (1999).

Single grains from selected high-grade samples were studied by ion microprobe (Secondary Ion Mass Spectrometry, SIMS) to look for microscale carbon isotopic zoning. Carbon isotope microanalyses of graphite were performed at CRPG-CNRS (Nancy, France) using a CAMECA ims-1270 ion microprobe. Gold-coated graphite polished section samples were sputtered with a $14 \mathrm{keV} \mathrm{Cs}^{+}$primary beam defocused to a $\sim 25-30 \mu \mathrm{m}$ diameter spot. Precision of the analyses is better than $\pm 1 \%$. Instrumental mass fractionation was corrected using graphite standards.

\section{Results}

Graphite occurrences in the Aracena Metamorphic Belt are only found in the continental domain. Disseminated graphite occurs in the low- to medium-grade metamorphic rocks of the La Umbría series as well as in the higher-grade rocks of the Fuente del Oro and calcsilicate series. In these high-grade rocks, graphite may form concentrations that had past economic interest (e.g. La Niña and Las Hormigas mines: Jubés \& Carbonell, 1918). Vein-type occurrences are restricted to high-grade rocks.

Table 1 summarizes the geological and mineralogical characteristics of the graphite occurrences recognized in the Aracena Metamorphic Belt. The low-grade rocks 
Table 1. Summary of the main geologic and mineralogical features of graphite occurrences in the Aracena Metamorphic Belt

\begin{tabular}{|c|c|c|c|c|c|c|c|c|c|c|}
\hline & $\begin{array}{l}\text { Mode of } \\
\text { occurrence }\end{array}$ & Host rock & Samples & Mineral association & $\begin{array}{l}\text { Graphite } \\
\text { content }\end{array}$ & c parameter $(\AA)$ & DTA max & $\begin{array}{c}\text { Average Raman } \\
\mathrm{D} /(\mathrm{D}+\mathrm{O}) \times 100 \text { ratio }\end{array}$ & Average $\delta^{13} \mathrm{C}$ & Age \\
\hline \multirow{4}{*}{$\begin{array}{l}\text { High-grade } \\
\text { occurrences }\end{array}$} & $\begin{array}{c}\text { Disseminated } \\
\text { to massive }\end{array}$ & $\begin{array}{l}\text { Leucogneisses } \\
\text { and quartzites } \\
\text { within the calc- } \\
\text { silicate series }\end{array}$ & $\begin{array}{l}\text { CC-1 to CC-5, } \\
\text { LH-0 to LH-5, } \\
\text { NI-0 to NI-11, } \\
\text { AC-1 to AC-5, } \\
\text { RB-1, RB-2 }\end{array}$ & $\begin{array}{l}\mathrm{Qtz}+\mathrm{Kfs}+\mathrm{Ms}+\mathrm{Bt}+ \\
\mathrm{Gr} \pm \mathrm{Grt} \pm \mathrm{Sil}\end{array}$ & High (up to $50 \%$ ) & $6.696-6.708$ & $775-832^{\circ} \mathrm{C}$ & $\begin{array}{l}1.2 \\
\left(L_{a}>2000 \AA\right)^{*} \\
\left(L_{a}=5175 \AA\right)^{* *}\end{array}$ & $-26.4 \%$ & $\begin{array}{r}\text { Cambrian-Late } \\
\text { Precambrian }\end{array}$ \\
\hline & Disseminated & $\begin{array}{l}\text { Gneisses of the } \\
\text { Fuente del } \\
\text { Oro series }\end{array}$ & $\begin{array}{l}\text { AF-1 to AF-3, } \\
\text { SA-1, SA-2 }\end{array}$ & $\begin{array}{l}\mathrm{Qtz}+\mathrm{Kfs}+\mathrm{Ms}+ \\
\quad \mathrm{Bt}+\mathrm{Gr}\end{array}$ & $\begin{array}{l}\text { Low (locally } \\
\text { medium; } \\
10-30 \% \text { ) }\end{array}$ & $6.700-6.704$ & $847^{\circ} \mathrm{C}$ & $\begin{array}{l}3.9 \\
\left(\mathrm{~L}_{\mathrm{a}}>2000 \AA\right)^{*} \\
\left(\mathrm{~L}_{\mathrm{a}}=2040 \AA\right)^{* *}\end{array}$ & $-28.0 \%$ & Precambrian \\
\hline & Disseminated & Tonalites & $\mathrm{MO}-1, \mathrm{WC}$ & $\begin{array}{l}\mathrm{Qtz}+\mathrm{Kfs}+\mathrm{Ab}+\mathrm{Bt}+ \\
\mathrm{Sil}+\mathrm{Crd} \pm \mathrm{Gr}\end{array}$ & $\begin{array}{l}\text { Very low } \\
\quad(<10 \%)\end{array}$ & 6.704 & $852^{\circ} \mathrm{C}$ & $\begin{array}{l}6.2 \\
\left(\mathrm{~L}_{\mathrm{a}}=1800 \AA\right)^{*} \\
\left(\mathrm{~L}_{\mathrm{a}}=1205 \AA\right)^{* *}\end{array}$ & $-24.7 \%$ & Precambrian \\
\hline & Veins & Mafic granulites & $\begin{array}{l}\text { LM-1A, LM-1B, } \\
\text { LM-2 }\end{array}$ & $\mathrm{Cpx}+\mathrm{Hbl}+\mathrm{Pl}+\mathrm{Bt}$ & $\begin{array}{l}\text { Very low } \\
\quad(<10 \%)\end{array}$ & $6.698-6.702$ & $858^{\circ} \mathrm{C}$ & $\begin{array}{l}5.3 \\
\left(\mathrm{~L}_{\mathrm{a}}=1950 \AA\right)^{*} \\
\left(\mathrm{~L}_{\mathrm{a}}=1315 \AA\right)^{* *}\end{array}$ & $-18.1 \%$ & Precambrian \\
\hline $\begin{array}{l}\text { Low-grade } \\
\text { occurrences }\end{array}$ & Disseminated & $\begin{array}{l}\text { Slates and } \\
\text { quartzites of La } \\
\text { Umbría series }\end{array}$ & LU-1 to LU-8 & $\mathrm{Qtz}+\mathrm{Ms}+\mathrm{Bt} \pm \mathrm{Gr}$ & $\begin{array}{l}\text { Very low } \\
\quad(<10 \%)\end{array}$ & $6.720-6.741$ & $580-610^{\circ} \mathrm{C}$ & n.d. & $-29.3 \%$ & Precambrian \\
\hline
\end{tabular}

Data for high-grade occurrences, except Raman D/O ratios, are from Rodas et al. (2000)

Mineral abbreviations after Kretz (1983): Crd - cordierite; Qtz - quartz; Grt - garnet; Kfs - K-feldspar; Sil - sillimanite; Ms - muscovite; Ab - albite; Hbl - hornblende; Gr - graphite; Bt - biotite;

$\mathrm{Pl}$ - plagioclase; $\mathrm{Cpx}$ - clinopyroxene.

${ }^{*} \mathrm{~L}_{\mathrm{a}}$ calculated after Wopenka \& Pasteris (1993); ${ }^{* *} \mathrm{~L}_{\mathrm{a}}$ calculated after Matthews et al. (1999). 


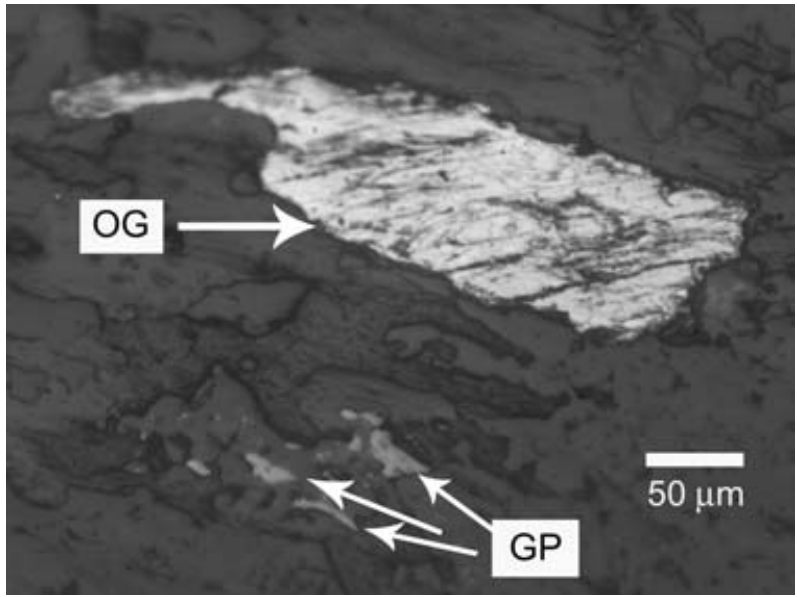

Figure 4. Reflected light microphotograph showing the two different types of 'graphite' in the metapelites from La Umbría series. OG - High-reflectance, optical graphite; GP - Lowreflectance, graphitized particles.

of the La Umbría series comprise biotite metapelites (locally carbonaceous) with interbedded schistose quartzites and quartz-amphibolites, representing the result of epizonal metamorphism reaching the biotite isograd. In particular, the carbonaceous slates within La Umbría series display a fine-grained texture defined by foliated aggregates of phyllosilicates and graphitized carbonaceous matter. Mineral association indicates that these rocks formed under greenschistfacies conditions. Reflected light microscopy reveals that these samples have two different types of 'graphite' randomly disseminated through the samples: one has the optical properties of graphite, that is, it is highly anisotropic and occurs as platy crystals $(>150 \mu \mathrm{m}$ in length) with high reflectance; the other consists of smaller $(<50 \mu \mathrm{m}$ long $)$, irregularly shaped 'graphitized particles' (Fig. 4). The term 'graphitized particles' is used here in the sense given by Diessel, Brothers \& Black (1978) to describe carbonaceous particles with much lower reflectance and anisotropy than graphite.

Bulk structural data consequently show a wide range of values for the $\mathrm{c}$ parameter of graphite consistent with temperatures from $300^{\circ} \mathrm{C}$ to over $600^{\circ} \mathrm{C}$, according to Shengelia, Akhvlediani \& Ketskhoveli (1979). Raman study has not been carried out on the low-grade samples since it was impossible to obtain grain separates of each type of particle. Temperatures of the exothermic peak in the DTA curves $\left(580-610^{\circ} \mathrm{C}\right)$ are within the range given for 'graphite' in greenschist-facies rocks (Kwiecinska, 1980; Petrova et al. 2002). Stable carbon isotope analyses on bulk concentrates provide light values $\left(\delta^{13} \mathrm{C}=-26.8\right.$ to -30.3 per mil relative to the PDB standard).

Details of the structural and mineralogical features of the graphite occurrences in the high-grade rocks have been previously described by Rodas et al. (2000). The structural characterization of graphite from highgrade occurrences by Raman spectroscopy carried out
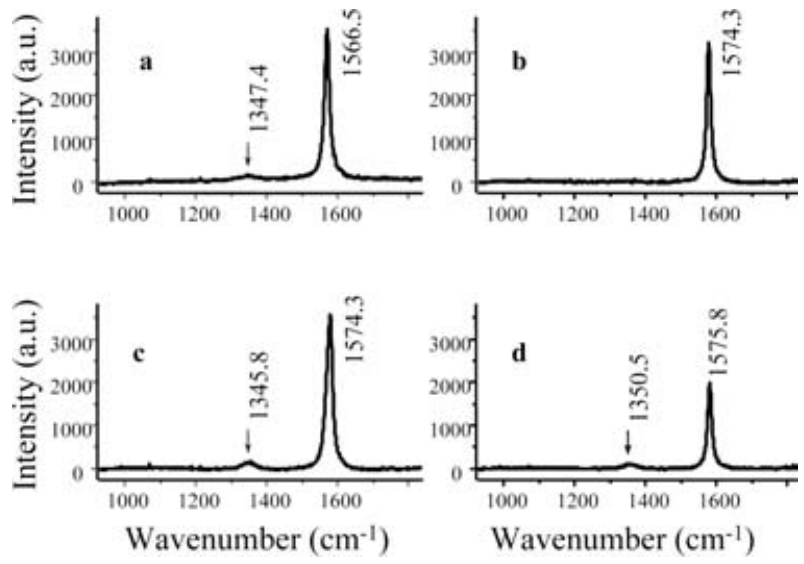

Figure 5. First-order Raman spectra of graphite from highgrade occurrences. (a) Syngenetic graphite from the Fuente del Oro series (sample AF-1); (b) syngenetic graphite from the calc-silicate series (sample NI-10); (c) epigenetic graphite from the mafic granulites (sample LM-2); (d) 'restitic' graphite in anatectic tonalites (sample MO-1).

in the present paper confirms the XRD data and shows a high degree of structural ordering (very low area ratio of disorder to order peak, large $\mathrm{L}_{\mathrm{a}}$ crystallite size; Table 1) along the basal plane (Fig. 5). Raman characteristics of different graphite grains from each occurrence are fairly homogeneous. Among the studied occurrences, graphite is slightly more crystalline in the calc-silicate series. Conversely, the disorder peak is better developed in the graphite samples from tonalites and vein-type occurrences, corresponding to lower $\mathrm{L}_{\mathrm{a}}$ values. Figure 6 shows that graphite in all the occurrences is within the range of graphite formed under granulite conditions.

SIMS analyses of graphite grains from two of the main deposits in the calc-silicate series (La Niña and Las Hormigas mines) show that graphite is isotopically heterogeneous. The inner part of graphite single crystals often has lighter $\delta^{13} \mathrm{C}$ values (close to $-27 \%$ ) while the external part of the same crystals has a heavier signature $\left(\delta^{13} \mathrm{C}\right.$ ranges from $-24.9 \%$ to $-22.2 \%$ ) (Fig. 7).

\section{Discussion}

\section{5.a. Syngenetic graphite}

Syngenetic graphite is formed through regional or contact metamorphism of carbonaceous matter dispersed in the sediments. As metamorphism proceeds, progressive changes in both physical properties and chemistry of carbonaceous particles are recorded at different graphitization stages.

Basins located between continental masses that later evolved to suture zones have been proved as suitable places for the accumulation and preservation of carbonaceous matter (Dissanayake, Chandrajith \& Boudou, 2000). Subsequent metamorphism could 


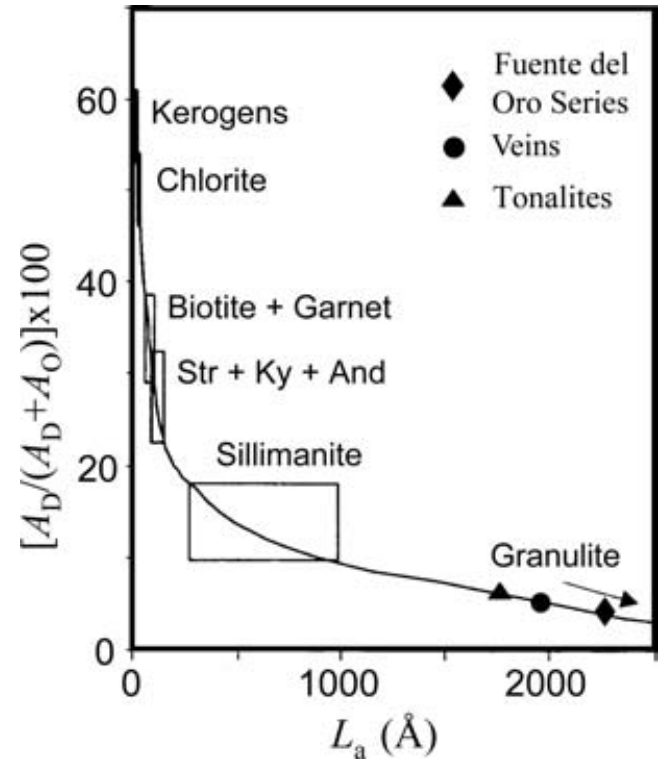

Figure 6. Relation between the area ratio of disorder (D) to order (O) Raman peaks and crystallite size along the $a-b$ plane $\left(L_{a}\right)$. The fields for the different metamorphic rocks are given by Wopenka \& Pasteris (1993). Note that the highest crystalline graphite in the Aracena Metamorphic Belt (graphite in the calc-silicate series) would be plotted out of the diagram. $\mathrm{Str}$ - staurolite; Ky - kyanite; And - andalusite.

transform these sedimentary rocks into graphite-rich schists and gneisses. Graphitic rocks in the Aracena Metamorphic Belt may therefore represent black shales that accumulated in the basin developed between the Ossa Morena Zone and the South Portuguese Zone of the Iberian Massif. The accumulation of organic matter should occur preferentially in distal parts of the platform, where clastic supply from the continent would have not diluted its concentration. The presence of two types of optically different 'graphite' in the rocks of the La Umbría series suggests that detrital graphite derived from the continent drainage system was incorporated into the sediments. Such highly crystalline, detrital graphite in association with 'in situ'-formed graphite of lower crystallinity has been recognized by different techniques in samples from many low-grade metamorphic terranes (Diessel, Brothers \& Black, 1978; Buseck \& Bo-Jun, 1985; Okuyama-Kusunose \& Itaya, 1987; Wada et al. 1994; Petrova et al. 2002). In any case, detrital graphite may point to the presence of carbonaceous matter prior to the Precambrian times represented by the materials of the La Umbría series and a former (higher-grade) metamorphic event. The light bulk isotopic signature (mean $\delta^{13} \mathrm{C}=-29.3 \%$ ) of the graphitized carbonaceous matter disseminated throughout the rocks of the La Umbría series points to the organic derivation of both types of 'graphite'.

'Restitic' graphite in the high-grade rocks (anatectic tonalites) has been interpreted to be the result of graphitization in the original clayey sediments of the La Umbría series up to ultrahigh temperatures (Rodas et al. 2000). The crystallochemical characteristics of

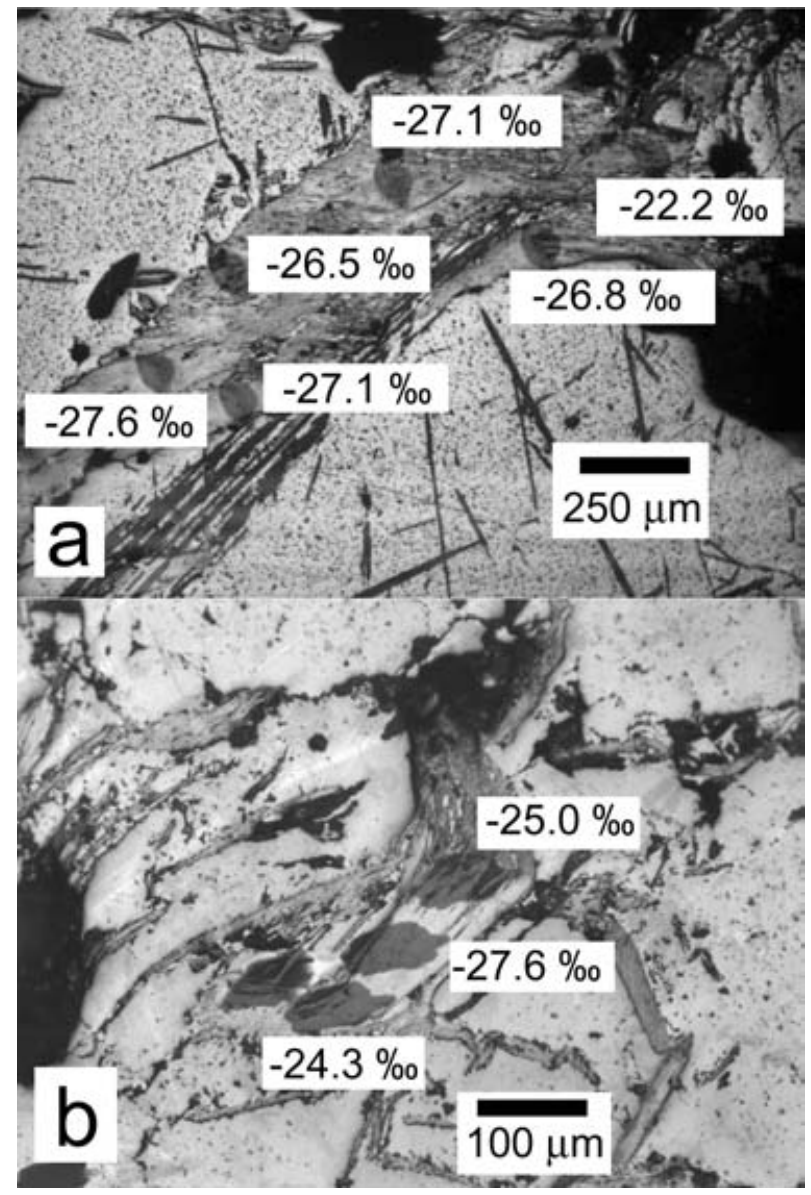

Figure 7. Two graphite grains from different high-grade occurrences within the calc-silicate series showing isotopic zoning. (a) Las Hormigas mine (sample LH-3); (b) La Niña mine (sample NI-10). Spots after SIMS analyses are labelled with $\delta^{13} \mathrm{C}$ values. Note that overgrowth by heavier fluid-deposited graphite has enlarged the metamorphic grains along the $\mathrm{a}-\mathrm{b}$ plane.

such graphite (see Table 1) are in agreement with the temperature estimated for these rocks located in the southern margin of the continental domain. Graphite in the tonalites is isotopically significantly heavier than its low-grade counterpart (mean $\delta^{13} \mathrm{C}=-24.7 \%$, that is, about $5 \%$ heavier on average). Along with bulk chemical changes in the composition of organic matter, an isotopic fractionation is also involved in the graphitization process. In the fractionation that occurs between two carbon-bearing phases, the more oxidized species of the pair becomes relatively enriched in the heavier isotope (Hoefs \& Frey, 1976; Scheele \& Hoefs, 1992; Luque, Rodas \& Barrenechea, 1999). If we consider a simple isotopic mass balance, taking into account that graphite content in the anatectic tonalites is $2 \%$ lower than that in the rocks of the La Umbría series and that $\Delta^{13} \mathrm{C}$ is about $5 \%$ (average $\delta^{13} \mathrm{C}$ of graphite in the anatectic tonalites is $-24.7 \%$, and average $\delta^{13} \mathrm{C}$ of graphite in the slates and quartzites of the La Umbría series is $-29.3 \%$ ), the isotopic signature of the gas released would be $\delta^{13} \mathrm{C} \approx-41 \%$. This value agrees with the estimated signature of methane (Hoefs, 1997). 
Therefore, it is not surprising that the residual graphite in the anatectic tonalites is isotopically heavier with respect to the original carbonaceous matter dispersed in the rocks of the La Umbría series. The production of methane would indicate low $f \mathrm{O}_{2}$ conditions.

Structural, thermal and chemical characteristics of graphite in the high-grade rocks of the Fuente del Oro series correspond to highly crystalline graphite (Rodas et al. 2000) and they are compatible with the high temperature estimated for the southern part of the Aracena Metamorphic Belt (Castro et al. 1996b). However, the higher content of graphite in these rocks with respect to the concentrations found in the La Umbría series needs further consideration. If both series were equivalent (as proposed by Bard, 1969), carbon content should either diminish with increasing metamorphic grade, or be constant if some graphite is reprecipitated during cooling after having dissolved. This would perhaps indicate that the La Umbría series and Fuente del Oro series are not equivalent as previously stated. An alternative explanation could be related to a different sedimentary environment for the Fuente del Oro series that should favour the accumulation and preservation of organic matter.

Finally, during Late Precambrian-Cambrian times the sedimentary basin that developed between the Ossa Morena Zone and the South Portuguese Zone could correspond to a continental shelf in which reducing conditions prevailed. In such an environment, lidites, sandstones and clayey sediments very enriched in carbonaceous matter were deposited within an impure carbonate sequence (the calc-silicate series). It is considered that this basin developed during the Cambrian rifting stage (Liñán \& Quesada, 1990) and it is well known that rift-basin type repositories can accumulate abundant organic matter (Dissanayake, Chandrajith \& Boudou, 2000). Considering the age of the beginning of the rifting stage, the age of the calc-silicate series should be re-examined. It must be emphasized that current dating of the calc-silicate series is based on regional correlation with lithologically similar series cropping out in low-grade areas of the Ossa Morena Zone. In any case, the calc-silicate series overlies the gneisses of the Fuente del Oro series, which are correlated with the Serie Negra of late Riphean age (Bard, 1969). Whether the calc-silicate series can be correlated to the Vendian synorogenic sequences or if it is otherwise related to the Cambrian rifting is difficult to elucidate. The presence of graphite-rich levels pointing to a rift-basin, as well as the occurrence of basic volcanic rocks interbedded within the sequence (which is typical of a rift scenario), apparently support our new hypothesis of a younger age.

\section{5.b. Epigenetic graphite}

Epigenetic graphite is deposited from $\mathrm{C}-\mathrm{O}-\mathrm{H}$ fluids when saturation is attained. Its characteristics and mechanisms of formation have been described in detail by Luque et al. (1998). Fluid-deposited graphite is typically highly crystalline, in contrast with metamorphic graphite that displays variable crystallinity depending upon its temperature of formation. The causes for fluid-deposited graphite to be highly crystalline have been examined by Luque \& Rodas (1999) and Pasteris (1999). Three conditions must be fulfilled to account for the formation of epigenetic graphite: (1) a hightemperature environment in which carbon is incorporated into $\mathrm{C}-\mathrm{O}-\mathrm{H}$ fluids through devolatilization and/or decarbonation reactions; (2) rock fracturing that provides channelways for fluid flow and mineral deposition (for vein-type graphite) or intergranular, pervasive flow (for the overgrowth of syngenetic graphite grains); and (3) appropriate mechanism(s) to cause graphite precipitation (changes in $T, P, f \mathrm{O}_{2}$, etc.). In principle, granulite-facies metamorphism provides the most suitable conditions for the development of epigenetic graphite, as exemplified by the large vein-type occurrences in Sri Lanka, India and Madagascar (Katz, 1987; Santosh \& Wada, 1993; Radhika \& Santosh, 1995) and by the graphite overgrowths described by Farquhar, Hauri \& Wang (1999).

Fluid-deposited graphite in the Aracena Metamorphic Belt comprises both vein-type and overgrowths on existing metamorphic grains. An extensional tectonic regime prevailed during the metamorphic peak (D2 phase) with associated massive flow of fluids (Díaz Azpiroz et al. 2004). This flow was mostly pervasive, and locally occurred along ductile shear zones. In contrast to other granulite-facies terranes where graphite veins are abundant (Sri Lanka, India), the Aracena Metamorphic Belt differs in that high temperatures were not accompanied by high pressure conditions. The peak metamorphic conditions attained for the rocks of the Aracena Metamorphic Belt were $T=c .1000^{\circ} \mathrm{C}$ and $P<6 \mathrm{kbar}$ (Castro et al. 1996a). Based on theoretical considerations of the $\mathrm{C}-\mathrm{O}-\mathrm{H}$ system, Pasteris (1999) indicated that fluids mobilized at low pressures might precipitate much of their carbon as overgrowths on pre-existing graphite crystals formed by 'in situ' metamorphism. Due to the pervasive flow of fluids close to the metamorphic peak in the Aracena Metamorphic Belt, there was a possibility of overgrowth of metamorphic graphite by fluid-deposited graphite. The isotopic zoning found in the disseminated graphite within the calc-silicate series supports this possibility. It can be argued that fluids derived their carbonic species mostly from the devolatilization of the carbonaceous metapelites. If this occurred under low $f \mathrm{O}_{2}$ conditions (as for 'restitic' graphite), the oxidation of $\mathrm{CH}_{4}$ released from devolatilization of carbonaceous matter would result in isotopically lighter rims (Farquhar, Hauri \& Wang, 1999). On the other hand, under higher $f \mathrm{O}_{2}$ conditions, devolatilization of hydrous phases releases $\mathrm{H}_{2} \mathrm{O}$, which, reacting with carbon, should produce $\mathrm{CO}_{2}$ and $\mathrm{CH}_{4}$ 
in similar amounts (Cesare, 1995). Precipitation from the reverse reaction $\left(\mathrm{CO}_{2}+\mathrm{CH}_{4}=2 \mathrm{C}+2 \mathrm{H}_{2} \mathrm{O}\right)$ would result in graphite with the same isotopic composition as that of the disseminated, syngenetic graphite. Therefore, devolatilization of the carbonaceous metapelites under reducing conditions generated methanerich fluids (as also described from other epigenetic occurrences in high-grade metamorphic rocks: e.g. Rumble, Duke \& Hoering, 1986). The contribution from heavy $\mathrm{CO}_{2}$ derived by decarbonation reactions of the carbonate lithologies supplied carbon to the fluids and this would explain the heavier isotopic signature of the external parts of the disseminated graphite crystals in the gneisses of the calc-silicate series. In this way much of the carbon in the fluids was locally precipitated as they moved, being unavailable for largescale transport and precipitation in veins.

Vein-type occurrences are found in mafic granulites cropping out in the highest-temperature area of the continental domain. Compared to the syngenetic occurrences, vein-type graphite is highly crystalline and isotopically heavier. Graphite from the veins even has a heavier isotopic signature than the overgrowths described above. Therefore, vein-type graphite occurrences of the Aracena Metamorphic Belt represent a different precipitation event. Rodas et al. (2000) stated that such veins are not only tectonically controlled but their occurrence also depends on textural characteristics, as evidenced by the occurrence of intracrystalline graphite veins along the cleavage planes of secondary amphibole in the mafic granulites. This textural relationship suggests that vein graphite might be formed during the retrograde metamorphism from granulite to amphibolite facies. The partial replacement of pyroxene by amphibole in the mafic granulites is indicative of hydration reactions acting during the retrograde metamorphism. In addition to cooling of the $\mathrm{C}-\mathrm{O}-\mathrm{H}$ fluid, it has been shown that hydration reactions involve relative carbon enrichment in the fluid due to $\mathrm{H}_{2} \mathrm{O}$ removal that, eventually, can result in graphite deposition (Rumble \& Hoering, 1986; Barrenechea et al. 1997; Luque et al. 1998; Farquhar, Hauri \& Wang, 1999).

Graphite veins in the Aracena Metamorphic Belt are very scarce and the individual dimensions of veins are very small. At first it could be concluded that the precipitation of graphite overgrowths from pervasive fluids precluded veining. However, these graphite veins have been interpreted as the result of precipitation from fluids which incorporated their carbon species by decarbonation and devolatilization reactions of the carbonate and metapelitic rocks of the calc-silicate series (Rodas et al. 2000). Since the rocks of the calc-silicate series should provide a huge amount of available carbon and the temperature conditions should be efficient enough to promote devolatilization reactions releasing $\mathrm{CH}_{4}$ and $\mathrm{CO}_{2}$ to the fluids (Wintsch et al. 1981; Ague, 2000), the scarcity of graphite veins

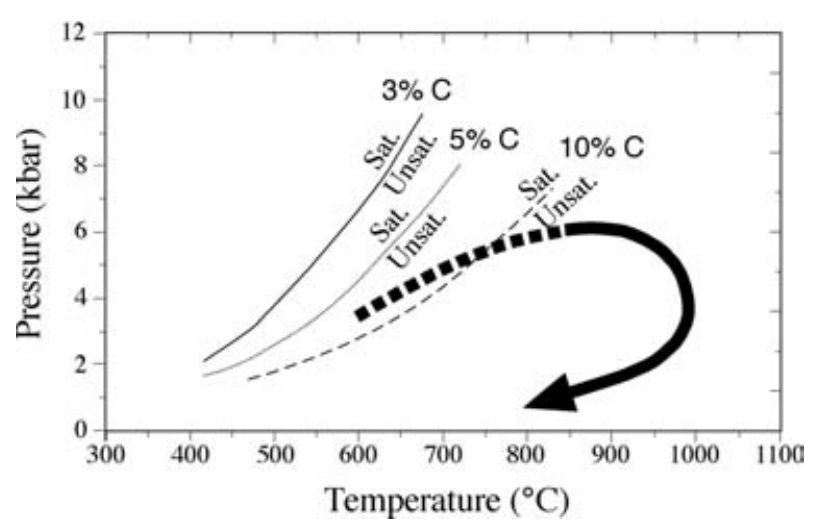

Figure 8. Graphite saturation curves for different carbon concentrations in $\mathrm{C}-\mathrm{O}-\mathrm{H}$ fluids (modified from Pasteris, 1999) and the $P-T$ path of the Aracena Metamorphic Belt. Note that, even for the highest carbon concentration in the fluids shown $(10 \% \mathrm{C})$, it is unlikely to precipitate graphite from such fluids under the estimated $P-T$ path.

could be interpreted in an alternative way. Considering the HT/LP conditions estimated for the Aracena Metamorphic Belt, if a $\mathrm{C}-\mathrm{O}-\mathrm{H}$ fluid undergoes a decrease in pressure, a large drop in temperature $\left(>300^{\circ} \mathrm{C}\right)$ is necessary to enter the graphite saturation field (Pasteris, 1999). Figure 8 shows the $P-T$ path of the pelitic granulites of the continental domain in the Aracena Metamorphic Belt and the graphite saturation curves for selected carbon isopleths. From this illustration it is clear that in a clockwise $P-T$ path, the trend is away from graphite saturation.

\section{5.c. Implications for the tectonothermal evolution of the Aracena Metamorphic Belt}

The results of this study cast some light on several debated aspects of the tectonic setting of the Aracena Metamorphic Belt in the Gondwana margin. In the lowgrade area, in accordance with the present knowledge of the areal distribution of the Cadomian metamorphism in the Aracena Metamorphic Belt (Ábalos \& Díaz Cusí, 1995), the Cadomian orogeny had little effect on the graphitization of the organic matter in the La Umbría series. Therefore, the presence of inherited graphite in the La Umbría series points to an orogenic cycle prior to the Cadomian, with an intense metamorphism well exceeding the greenschists facies. This corroborates the findings of de la Rosa, Jenner \& Castro (2002), based on the study of inherited zircon cores in anatectic granitoids from the Aracena Metamorphic Belt. In addition, conglomerates within the La Umbría series contain foliated pebbles, suggesting the activity of a Precambrian deformational event.

The differences in the organic matter contents between La Umbría and Fuente del Oro series and their relation to different sedimentary environments is a new topic entirely due to the graphite analysis. Therefore, it can be suggested that regional correlations between both series are not correct, which has profound 


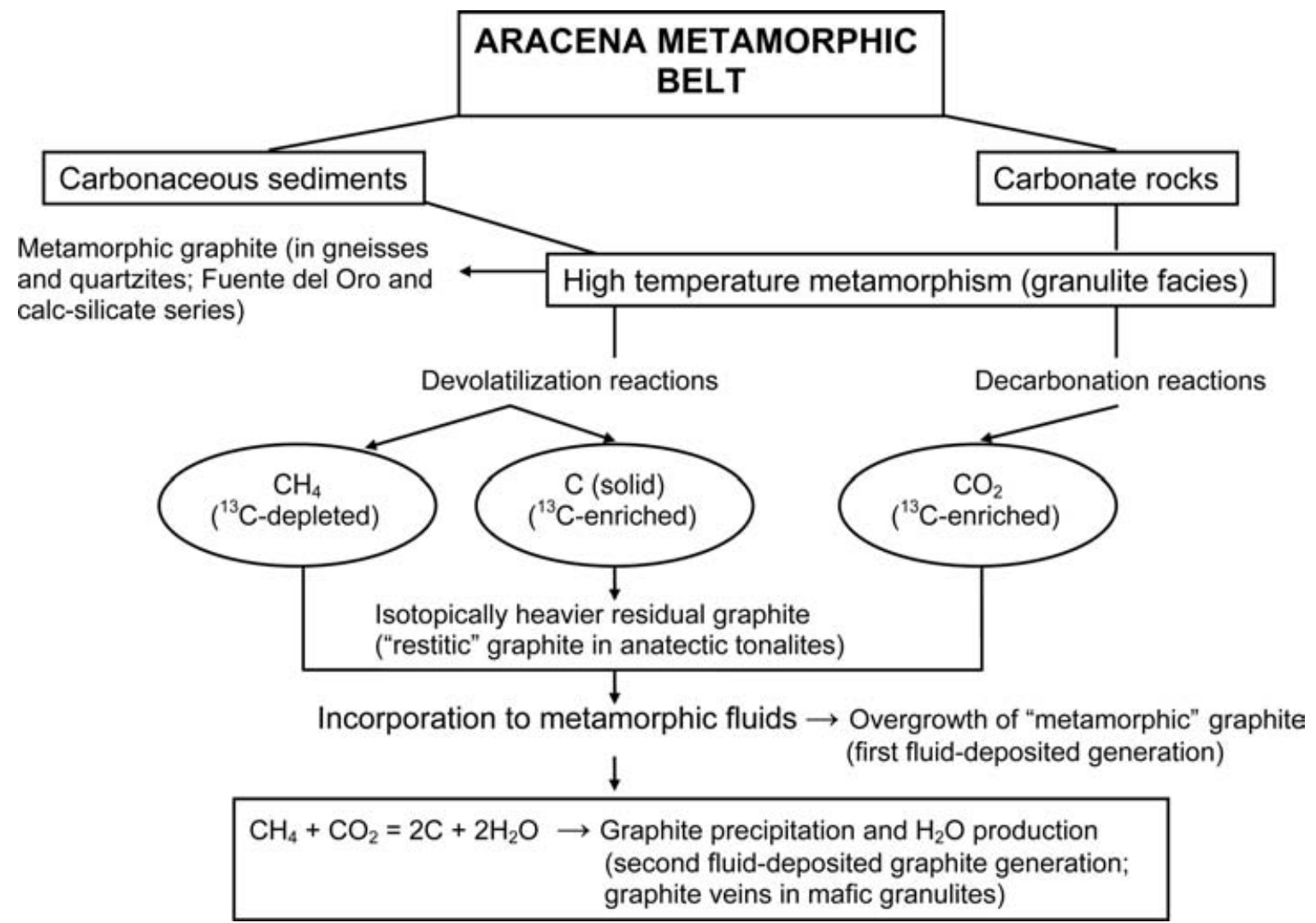

Figure 9. Diagram summarizing the processes leading to graphite generation in the high-grade metamorphic rocks of the Aracena Metamorphic Belt.

implications for the understanding of the tectonic evolution of the Aracena Metamorphic Belt. With respect to the calc-silicate series, its large organic matter content is in accordance with a rifting tectonic scenario, suggesting a Cambrian age for this formation. The structural characteristics of graphite are compatible with the UHT/LP metamorphism that affected the southern Aracena Metamorphic Belt in late Palaeozoic times, during the Variscan orogeny. Coinciding with field observations (Díaz Azpiroz et al. 2004), a pervasive flow of fluids resulting in the overgrowth of existing syngenetic graphite grains is also deduced from the present study.

The complete sequence of graphite-forming events in the high-temperature area of the Aracena Metamorphic Belt has been schematically outlined in Fig. 9, in which four graphite generations are recognized. The first two generations correspond to syngenetic graphite, namely 'metamorphic' graphite in gneisses and quartzites of the Fuente del Oro and calc-silicate series, and 'restitic' graphite in anatectic tonalites; the latter two graphite generations were precipitated from fluids and they correspond to the overgrowths on the pre-existing 'metamorphic' graphite, and to the veins associated with mafic granulites.

Acknowledgements. The authors wish to express their gratitude to R. Rojas (Instituto de Ciencia de Materiales de Madrid), J.-P. Boudou (Université Pierre et Marie Curie,
Paris), and E. Deloule (CNRS-CRPG, Nancy) for technical assistance and facilities provided during the thermal analysis, Raman spectroscopy study, and SIMS analyses, respectively. We thank P. Nabelek, B. Cesare and an anonymous referee for constructive criticisms that greatly improved this paper. This paper is a contribution from project PB98-0836 of the Spanish CICYT.

\section{References}

ÁBAlos, B. \& DíAz Cusí, J. 1995. Correlation between seismic anisotropy and major geological structures in SW Iberia: a case study on continental lithosphere deformation. Tectonics 14, 1021-40.

Ábalos, B., Gil Ibarguchi, J. I. \& Eguiluz, L. 1991. Structural and metamorphic evolution of the Almaden de la Plata Core (Sevilla, Spain) in relation to synmetamorphic shear between the Ossa-Morena and South Portuguese zones of the Iberian Variscan fold belt. Tectonophysics 191, 365-87.

AGUE, J. J. 2000. Release of $\mathrm{CO}_{2}$ from carbonate rocks during regional metamorphism of lithologically heterogeneous crust. Geology 28, 1223-6.

BARD, J. P. 1969. Le métamorphisme régional progressif de Sierra de Aracena en Andalousie occidentale (Espagne). Thèse d'État, Univ. de Montpellier, 398 pp. (published).

BARRENeCheA, J. F., LuQue, F. J., RodAs, M. \& PASTERIS, J. D. 1997. Vein-type graphite in Jurassic volcanic rocks of the External Zone of the Betic Cordillera, southern Spain. Canadian Mineralogist 35, 1379-90.

Beyssac, O., Rouzaud, J.-N., Goffé, B., BRunet, F. \& ChopIn, C. 2002a. Graphitization in a high-pressure, 
low-temperature metamorphic gradient: a Raman microspectroscopy and HRTEM study. Contributions to Mineralogy and Petrology 143, 19-31.

Beyssac, O., Goffé, B., Chopin, C. \& Rouzaud, J.-N. $2002 b$. Raman spectra of carbonaceous material in metasediments: a new geothermometer. Journal of Metamorphic Geology 20, 859-71.

BuseCK, P. R. \& Bo-Jun, H. 1985. Conversion of carbonaceous material to graphite during metamorphism. Geochimica et Cosmochimica Acta 49, 2003-16.

Castro, A., Fernández, C., De la Rosa, J. D., MorenoVentas, I., El-Hmidi, H., El-Biad, M., Bergamín, J. F. \& SÁNCHEZ, N. 1996a. Triple-junction migration during Paleozoic plate convergence: the Aracena metamorphic belt, Hercynian massif, Spain. Geologische Rundschau 85, 180-5.

Castro, A., Fernández, C., DE la Rosa, J. D., MorenoVENTAS, I. \& Rogers, G. 1996b. Significance of MORB-derived amphibolites from the Aracena Metamorphic Belt, Southwest Spain. Journal of Petrology 37, 235-60.

Castro, A., Fernández, C., El-HMidi, H., El-Biad, M., DÍAZ, M., DE LA RosA, J. D. \& STUART, F. 1999. Age constraints to the relationships between magmatism, metamorphism and tectonism in the Aracena metamorphic belt, southern Spain. International Journal of Earth Sciences 88, 26-37.

Cesare, B. 1995. Graphite precipitation in $\mathrm{C}-\mathrm{O}-\mathrm{H}$ fluid inclusions: closed system compositional and density changes, and thermobarometric implications. Contributions to Mineralogy and Petrology 122, 25-33.

DAllmeYer, R. D., FonseCA, P. E., QuesadA, C. \& RIBEIRO, A. 1993. ${ }^{40} \mathrm{Ar} /{ }^{\beta 9} \mathrm{Ar}$ mineral age constraints for the tectonothermal evolution of a Variscan suture in southwest Iberia. Tectonophysics 222, 177-94.

DE LA RosA, J. D., JENNER, G. A. \& CASTRO, A. 2002. A study of inherited zircons in granitoid rocks from the South Portuguese and Ossa-Morena Zones, Iberian Massif: support for the exotic origin of the South Portuguese Zone. Tectonophysics 352, 245-56.

Díaz AzPiroz, M., CASTRO, A., Fernández, C., LóPez, S., Fernández CAliani, J. C. \& Moreno-Ventas, I. 2004. The contact between the Ossa-Morena and the South Portuguese zones. Characteristics and significance of the Aracena metamorphic belt, in its central sector between Aroche and Aracena (Huelva). Journal of Iberian Geology 30, 23-51.

Diessel, P. R., Brothers, R. N. \& Black, P. M. 1978. Coalification and graphitization in high-pressure schists in New Caledonia. Contributions to Mineralogy and Petrology 68, 63-78.

Dissanayake, C. B., Chandrajthi, R. \& Boudou, J.-P. 2000. Biogenic graphite as a potential geomarker-Application to continental reconstructions of Pan-African Gondwana terrains. Gondwana Research 3, 405-13.

FARQUHAR, J., HAURI, E. \& WANG, J. 1999. New insights into carbon fluid chemistry and graphite precipitation: SIMS analysis of granulite facies graphite from Ponmudi, South India. Earth and Planetary Science Letters 171, 607-21.

FERnÁNDEZ-RodríGUEZ, C., Fernández CALIANi, J. C., Miras, A., BarrenecheA, J. F., LuQue, F. J. \& RoDAs, M. 1996. Nuevos datos geológicos sobre las mineralizaciones de grafito de la Banda Metamórfica de Aracena, Huelva (Macizo Ibérico Meridional). Geogaceta 20(7), 1576-7.
Giese, U., von Hoegen, R., Hoymann, K. H., Kramm, U. \& WALTER, R. 1994. The Palaeozoic evolution of the Ossa-Morena zone and its boundary to the South Portuguese zone in SW Spain: Geological constraints and geodynamic interpretation of a suture in the Iberian Variscan orogen. Neues Jahrbuch für Geologie und Paläontologie Abhandlungen 192, 333-60.

GREW, E. S. 1974. Carbonaceous material in some metamorphic rocks of New England and other areas. Journal of Geology 82, 50-73.

HoEfS, J. 1997. Stable Isotope Geochemistry, 4th ed. Berlin: Springer, $201 \mathrm{pp}$.

HoEfS, J. \& FrEY, M. 1976. The isotopic composition of carbonaceous matter in a metamorphic profile of the Swiss Alps. Geochimica et Cosmochimica Acta 40, 945 51.

ITAYA, T. 1981. Carbonaceous material in pelitic schists of the Sanbagawa metamorphic belt in central Shikoku, Japan. Lithos 14, 215-24.

JuBÉS, E. \& CARBONELL, A. 1918. Informe sobre los yacimientos de grafito de la zona de AlmonasterCortegana (Huelva). Boletín Oficial de Minería y Metalurgia 9, 12, 14, 15, 16.

KATZ, M. B. 1987. Graphite deposits of Sri Lanka: a consequence of granulite facies metamorphism. Mineralium Deposita 22, 18-25.

Kitchen, N. E. \& VAlley, J. W. 1995. Carbon isotope thermometry in marbles of the Adirondack Mountains, New York. Journal of Metamorphic Geology 13, 57794.

KRETZ, R. 1983. Symbols for rock-forming minerals. American Mineralogist 68, 277-9.

KWIECINSKA, B. 1980. Mineralogy of natural graphites. Polska Akademi Nauk, Prace Mineralogiczne 67, 5-79.

Liñán, E. \& QuesadA, C. 1990. Ossa Morena Zone. Stratigraphy. Rift phase (Cambrian). In Pre-Mesozoic Geology of Iberia (eds R. D. Dallmeyer and E. Martinez Garcia), pp. 259-66. Berlin: Springer Verlag.

LuQue, F. J., BARRENEChEA, J. F. \& RodAs, M. 1993. Graphite geothermometry in low and high temperature regimes: two case studies. Geological Magazine 130, 501-11.

Luque, F. J., Pasteris, J. D., Wopenka, B., Rodas, M. \& BARRENECHEA, J. F. 1998. Natural fluid-deposited graphite: Mineralogical characteristics and mechanisms of formation. American Journal of Science 298, 471-98.

LUQUE, F. J. \& RODAS, M. 1999. Constraints on graphite crystallinity in some Spanish fluid-deposited occurrences from different geologic settings. Mineralium Deposita 34(2), 215-19.

LUQUE, F. J., RoDAs, M. \& BARRENECHEA, J. F. 1999. Graphite deposits in southern Spain: Role of carbon isotopes in defining genetic models. In Mineral Deposits: Processes to Processing, vol. 2 (ed. C. J. Stanley), pp. 1117-20. Rotterdam: A. A. Balkema.

Matthews, M. J., Pimenta, M. A., Dresselhaus, G., Dresselhaus, M. S. \& ENDO, M. 1999. Origin of dispersive effects of the Raman $D$ band in carbon materials. Physical Review B 59, 6585-8.

OKUYAMA-KUSUNOSE, Y. \& ITAYA, T. 1987. Metamorphism of carbonaceous material in the Tono contact aureole, Kitakami Mountains, Japan. Journal of Metamorphic Geology 7, 121-39.

PASTERIS, J. D. 1999. Causes of the uniformly high crystallinity of graphite in large epigenetic deposits. Journal of Metamorphic Geology 17, 779-87. 
PAsteRIS, J. D. \& ChOU, I. M. 1998. Fluid-deposited graphitic inclusions in quartz: Comparison between KTB (German continental deep-drilling) core samples and artificially re-equilibrated natural inclusions. Geochimica et Cosmochimica Acta 62, 109-22.

Patiño Douce, A., Castro, A. \& El-Biad, M. 1997. Thermal evolution and tectonic implications of spinelcordierite granulites from the Aracena metamorphic belt, Southwest Spain. GAC/MAC Annual Meeting, Ottawa, Abstracts, A-113.

Petrova, T. V., Ferreiro-Mählmann, R., Stern, W. B. \& FREY, M. 2002. Application of combustion and DTATGA analysis to the study of metamorphic organic matter. Schweizerische Mineralogische und Petrologische Mitteilungen 82, 33-53.

QuesadA, C., FonseCA, P. E., Munha, J., Oliveira, J. T. \& RIBEIRO, A. 1994. The Beja-Acebuches ophiolite (Southern Iberia Variscan fold belt): Geological characterization and geodynamic significance. Boletín Geológico y Minero 105, 3-49.

RADHIKA, U. P. \& SANTOSH, M. 1995. A comparative study of graphite occurrences in South India, Sri Lanka and Madagascar within East Gondwana. In India as a Fragment of East Gondwana (eds M. Yoshida, M. Santosh and A. T. Rao), pp. 143-57. Gondwana Research Group Memoir no. 2. Field Science Publishers.

RodAs, M., LuQue, F. J., BARRENECHEA, J. F., FERnÁNDEZCaliani, J. C., Miras, A. \& FernándeZ-Rodríguez, C. 2000. Graphite occurrences in the low-pressure/hightemperature metamorphic belt of the Sierra de Aracena (southern Iberian Massif). Mineralogical Magazine 64, 801-14.

Rumble, D., Duke, E. F. \& Hoering, T. C. 1986. Hydrothermal graphite in New Hampshire: Evidence of carbon mobility during regional metamorphism. Geology 14, $452-5$.

Rumble, D. \& Hoering, T. C. 1986. Carbon isotope geochemistry of graphite vein deposits from New Hampshire, U.S.A. Geochimica et Cosmochimica Acta 50, 1239-47.

SANTOSH, M. \& WADA, H. 1993. A carbon isotope study of graphites from the Kerala Khondalite Belt, Southern
India: evidence for $\mathrm{CO}_{2}$ infiltration in granulites. Journal of Geology 101, 643-51.

SATISH-Kumar, M., WADA, H. \& SANTOSH, M. 2002. Constraints on the application of carbon isotope thermometry in high- to ultrahigh-temperature metamorphic terranes. Journal of Metamorphic Geology 20, $335-50$.

SCHEELE, N. \& HoEFs, J. 1992. Carbon isotope fractionation between calcite, graphite and $\mathrm{CO}_{2}$ : an experimental study. Contributions to Mineralogy and Petrology 112, $35-45$.

Shengelia, D. M., Akhvlediani, R. A. \& Ketskhoveli, D. N. 1979. The graphite geothermometer. Doklady Academi Nauk SSSR 235, 132-4.

Ueno, Y., Yurimoto, H., Yoshioka, H., Komiya, T. \& MARUYAMA, S. 2002. Ion microprobe analysis of graphite from ca. $3.8 \mathrm{Ga}$ metasediments, Isua supracrustal belt, West Greenland: Relationship between metamorphism and carbon isotopic composition. Geochimica et Cosmochimica Acta 66, 1257-68.

WadA, H., TOMita, T., MatsuURA, K., IUChI, K., ItO, M. \& MORIKIYO, T. 1994. Graphitization of carbonaceous matter during metamorphism with references to carbonate and pelitic rocks of contact and regional metamorphisms, Japan. Contributions to Mineralogy and Petrology 118, 217-28.

Wilde, S. A., DORSETt-BAin, H. L. \& LenNON, R. G. 1999. Geological setting and controls on the development of graphite, sillimanite and phosphate mineralization within the Jiamusi Massif: an exotic fragment of Gondwanaland located in north-eastern China? Gondwana Research 2, 21-46.

Wintsch, R. P., O'Connell, A. F., Ransom, B. L. \& WiECHMANN, M. J. 1981. Evidence for the influence of $\mathrm{f}_{\mathrm{CH} 4}$ on the crystallinity of disseminated carbon in greenschits facies rocks, Rhode Island, USA. Contributions to Mineralogy and Petrology 77, 20713.

WOPENKA, B. \& PASTERIS, J. D. 1993. Structural characterization of kerogens to granulite-facies graphite: Applicability of Raman microprobe spectroscopy. American Mineralogist 78, 533-57. 